\author{
Ingibjörg Eir Einarsdóttir · Nadia Silva \\ Deborah M. Power · Heiddis Smáradóttir \\ Björn Thrandur Björnsson
}

\title{
Thyroid and pituitary gland development from hatching through metamorphosis of a teleost flatfish, the Atlantic halibut
}

Accepted: 9 September 2005 / Published online: 8 December 2005

(C) Springer-Verlag 2005

\begin{abstract}
Fish larval development, not least the spectacular process of flatfish metamorphosis, appears to be under complex endocrine control, many aspects of which are still not fully elucidated. In order to obtain data on the functional development of two major endocrine glands, the pituitary and the thyroid, during flatfish metamorphosis, histology, immunohistochemistry and in situ hybridization techniques were applied on larvae of the Atlantic halibut (Hippoglossus hippoglossus), a large, marine flatfish species, from hatching through metamorphosis. The material was obtained from a commercial hatchery. Larval age is defined as day-degrees $\left(\mathrm{D}^{\circ}=\right.$ accumulated daily temperature from hatching). Sporadic thyroid follicles are first detected in larvae at $142 \mathrm{D}^{\circ}$ (27 days post-hatch), prior to the completion of yolk sack absorption. Both the number and activity of the follicles increase markedly after yolk sack absorption and continue to do so during subsequent development. The larval triiodothyronine $\left(\mathrm{T}_{3}\right)$ and thyroxine $\left(\mathrm{T}_{4}\right)$ content increases, subsequent to yolk absorption, and coincides with the proliferation of thyroid follicles. A second increase of both $\mathrm{T}_{3}$ and $\mathrm{T}_{4}$ occurs around the start of metamorphosis and the $T_{3}$ content further increases at the metamorphic climax. Overall, the $T_{3}$ content is lower than $T_{4}$. The pituitary gland can first be distinguished as a separate organ at the yolk sack stage. During subsequent development, the gland becomes more elongated and differentiates into neurohy-
\end{abstract}

I. E. Einarsdóttir $(\bowtie) \cdot$ B. T. Björnsson

Fish Endocrinology Laboratory,

Department of Zoology/Zoophysiology, Göteborg University,

Box 463, 40530 Göteborg, Sweden

E-mail: ingibjorg.einarsdottir@zool.gu.se

Tel : + 46-31-7733684

Fax: +46-31-7733807

N. Silva $\cdot$ D. M. Power

Centro de Ciências do Mar, Universidade do Algarve,

Campus de Gambelas, 8000-139 Faro, Portugal

H. Smáradóttir

Fiskeldi Eyjafjarðar Ltd., Glerárgata 34, IS-600 Akureyri, Iceland pophysis $(\mathrm{NH})$, pars distalis $(\mathrm{PD})$ and pars intermedia (PI). The first sporadic endocrine pituitary cells are observed at the yolk sack stage, somatotrophs (growth hormone producing cells) and somatolactotrophs (somatolactin producing cells) are first observed at $121 \mathrm{D}^{\circ}$ (23 days post-hatch), and lactotrophs (prolactin producing cells) at $134 \mathrm{D}^{\circ}$ (25 days post-hatch). Scarce thyrotrophs are evident after detection of the first thyroid follicles $\left(142 \mathrm{D}^{\circ}\right)$, but coincident with a phase in which follicle number and activity increase $\left(260 \mathrm{D}^{\circ}\right)$. The somatotrophs are clustered in the medium ventral region of the $\mathrm{PD}$, lactotrophs in the anterior part of the PD and somatolactotrophs are scattered in the mid and posterior region of the pituitary. At around $600 \mathrm{D}^{\circ}$, coinciding with the start of metamorphosis, somatolactotrophs are restricted to the interdigitating tissue of the NH. During larval development, the pituitary endocrine cells become more numerous. The present data on thyroid development support the notion that thyroid hormones may play a significant role in Atlantic halibut metamorphosis. The time of appearance and the subsequent proliferation of pituitary somatotrophs, lactotrophs, somatolactotrophs and thyrotrophs indicate at which stages of larval development and metamorphosis these endocrine cells may start to play active regulatory roles.

Keywords Flatfish · Pituitary · Thyroid · Metamorphosis $\cdot$ Hippoglossus hippoglossus

\section{Introduction}

The Atlantic halibut (Hippoglossus hippoglossus) is the largest existent flatfish species with adult individuals being able to reach body weights well over $200 \mathrm{~kg}$. This marine teleost is a batch spawner and each female spawns several batches of eggs over a period of approximately 4 weeks. Egg and larval growth and development are both temperature- and time-dependent and both factors are included in the definition of age as 
day-degrees $\left(\mathrm{D}^{\circ}=\right.$ accumulated daily temperature $\left({ }^{\circ} \mathrm{C}\right)$ from hatching). The hatched larvae are relatively small, pelagic and symmetrical. The yolk sack period lasts for 240-260 $\mathrm{D}^{\circ}$ (46-50 days post-hatch), depending on the temperature, after which the larvae start to feed (first feeding) on live zooplankton (Olsen et al. 1999). At around $600-650 \mathrm{D}^{\circ}$ (79-84 days post-hatch), the larvae start to undergo a major morphological restructuring, the metamorphosis. During this process, the body depth of the larvae increases notably and the left eye starts to migrate over to the right side. Thus, the larvae become cranially asymmetrical. At the same time, the skin pigmentation also becomes asymmetrical, with a dark right (upper) side and a white left (under) side. The larvae descend to the bottom to continue life as a benthic flatfish. The metamorphic process takes $2-3$ weeks and metamorphosed halibut, older than $800 \mathrm{D}^{\circ}$ (around 100 days post-hatch) are classified as juveniles.

Hormones play an important role in regulating developmental processes. The importance of the thyroid hormones (THs), thyroxine $\left(\mathrm{T}_{4}\right)$ and triiodothyronine $\left(\mathrm{T}_{3}\right)$, in vertebrate development is well established (Hadley 1992; Tata et al. 1993; Power et al. 2001). In fish, prior to the maturation of the larval thyroid gland, fish eggs and, subsequently, the larval yolk sack contain significant amounts of THs of maternal origin (Kobuke et al. 1987; Tagawa and Hirano 1987; Brown et al. 1988; Greenblatt et al. 1989; Tagawa et al. 1990a, b). This source of THs is likely to be of importance for the physiological regulation of growth, development and osmoregulation in larvae prior to the development of functional endogenous thyroid follicles. In fish, THs are also involved in the transition from the larval to the juvenile stage, the most dramatic manifestation of which is flatfish metamorphosis. Elevated endogenous $\mathrm{TH}$ concentrations have been observed during metamorphosis in the Japanese flounder (Paralichthys olivaceus) and the summer flounder (Paralichthys dentatus) (Tagawa et al. 1990a, b; Schreiber and Specker 1998) and TH treatments stimulated flatfish metamorphosis (Inui and Miwa 1985; Miwa and Inui 1987a; Solbakken et al. 1999) and the transformation from larvae to juvenile in round fish (Reddy and Lam 1992; de Jesus et al. 1998; Solbakken et al. 1999; Deane and Woo 2003). In contrast, exposure to inhibitors of TH synthesis retarded the classical metamorphosis, as observed in flatfish (Inui and Miwa 1985; Miwa and Inui 1987a) as well as the larvaljuvenile transition observed in other teleost species (Dales and Hoar 1954; Okimoto et al. 1993).

The activity of the thyroid gland is primarily regulated by a thyroid stimulating hormone (TSH, thyrotropin) secreted from the thyrotrophs of the pituitary gland. Thus, TSH plays an important role in the endocrine regulation of fish larval development and the temporal and quantitative appearance of thyrotrophs may act as an indicator of the onset and degree of thyroid follicle activity. Studies on the ontogeny of thyrotrophs in teleost fish are scarce, but indicate that the first appearance of thyrotrophs varies considerably among the teleost species. Thyrotrophs are detected before hatching in salmonids (Naito et al. 1993; Saga et al. 1993), at hatching in sea bream (Sparus aurata) (Ayala et al. 2003), and shortly after hatching in Japanese flounder and sea bass (Dicentrarchus labrax) (Miwa and Inui 1987b; Cambre et al. 1990) whereas, in the ayu (Plecoglossus altivelis), thyrotrophs appear as late as 50 days after hatching (Saga et al. 1999). Unexpectedly, in Japanese eel (Anguilla japonica), Anguilla obscura and Anguilla bicolor TSH immunoreactive cells are first seen just prior to the onset of metamorphosis, the transition from leptocephalus to glass eel, while active $T_{4}$ producing cells are earlier observed in the leptocephalus stage. Thus, it has been assumed that early on in eel ontogeny, TH production is independent of TSH regulation (Ozaki et al. 2000).

Other pituitary hormones that may also be candidate regulators of larval development are growth hormone $(\mathrm{GH})$, prolactin (PRL) and somatolactin (SL), due to their pluripotent actions in juvenile and adult fish. GH is produced in somatotrophs and, in teleosts, it is the principal growth-promoting hormone, affecting various aspects of energy metabolism, food conversion and appetite, while also playing an important role in osmoregulation as well as in reproduction and immune function (Peter and Marchant 1995; Björnsson 1997; Perez-Sanchez 2000; Björnsson et al. 2002). PRL, produced in lactotrophs, is a versatile hormone, having an amazing array of functions in different vertebrate classes (Bole-Feysot et al. 1998). In freshwater and euryhaline teleosts, including some flatfishes, a major function appears to be osmoregulation (Gutt 1985; McCormick 2001; Wada et al. 2004). Other functions of PRL in vertebrates include the regulation of growth, development, metabolism, stimulation of endocrine glands, behavior, reproduction and immune function (BoleFeysot et al. 1998; Forsyth and Wallis 2002). SL, produced in somatolactotrophs, was first discovered in the pituitary of the flounder (Ono et al. 1990) and has, subsequently, been shown to be involved in the regulation of adiposity and gonadal function in salmonids and sparid fish (Company et al. 2001), to have a hypercalcemic action in rainbow trout (Oncorhynchus mykiss) in fresh water (Kakizawa et al. 1993), to alter transepithelial transport of inorganic phosphate in monolayer cultures of flounder (Pleuronectes americanus) renal proximal tubuli epithelium (Renfro 1997), to be involved in the retention of $\mathrm{HCO}_{3}^{-}$ions during acidosis in rainbow trout (Kakizawa et al. 1997), and to have an effect on cryptic coloration in red drum (Sciaenops ocellatus) scales (Zhu and Thomas 1997).

While GH, PRL and SL have direct actions at the somatic tissue level, the pituitary also acts as a master gland, which regulates the activity of other endocrine glands, in particular, the thyroid, the adrenals (interrenal tissue in fish) and the gonads. In all vertebrates, the pituitary is located ventral to the hypothalamus. It consists of the adenohypophysis (AH), in which the hormone-producing cells are located, and the neurohy- 
pophysis (NH), which, in mammals, is a separate lobe located posterior of the $\mathrm{AH}$. In teleost fish, the $\mathrm{NH}$ instead interdigitates with the dorsal part of the AH (Ball and Baker 1969; Yadav 1995; Norris 1997). Studies of pituitary ontogeny in a range of round fish demonstrate that the AH consists of structurally separate parts; the rostral pars distalis (RPD), the proximal pars distalis (PPD) and the pars intermedia (PI) (Batten and Ingleton 1986; Huang and Specker 1994). The formation of the pituitary takes place in the embryo of all vertebrates. In mammals, the $\mathrm{AH}$ originates from an invagination of the oral ectoderm, Rathke's pouch, which detaches from the stomodeum and forms the pars distalis (PD) and PI of the pituitary. The NH, on the other hand, is of neural origin, arising from a ventral evagination of the ventral diencephalon (Ball and Baker 1969; Yadav 1995; Norris 1997). Recent studies on zebrafish (Danio rerio) indicate that teleosts do not form a Rathke's pouch. Rather, the AH develops from a primodeum of pituitary cells in the anterior neural ridge and moves, together with stomodeum cells, inwards in the process of oral cavity formation (Glasgow et al. 1997; Herzog et al. 2003; Sbrogna et al. 2003; Chapman et al. 2005). The architecture of the fish $\mathrm{AH}$, including the pattern of cellular arrangement and the timing and order of the first appearance of endocrine cells, varies among different groups and species (Yadav 1995). However, in many fish species, somatotrophs, lactotrophs and somatolactotrophs are confined to the same structural area of the pituitary. Accordingly, in striped bass (Morone saxatil$i s$ ), African catfish (Clarias gariepinus), European eel ( $A$. anguilla), sea bream, sea bass, chum salmon, rainbow trout, ayu, American shad (Alosa sapidissima) and the cichlid fish (Cichlasoma dimerus), somatotrophs are localized in the PPD and lactotrophs in the RPD (Cambre et al. 1990; Power and Canario 1992; Naito et al. 1993; Saga et al. 1993, 1999; Huang and Specker 1994; Volckaert et al. 1999; Pandolfi et al. 2001; Grandi et al. 2003; Laiz-Carrion et al. 2003), and in sea bream, European eel, ayu and American shad, somatolactotrophs are located in the PI (Villaplana et al. 1997; Saga et al. 1999; Grandi et al. 2003; Laiz-Carrion et al. 2003). The spatial distribution of immunoreactive endocrine cells in a chondrostean species (Acipenser naccarii) follows the same pattern as in teleost fishes, indicating a similar course of development (Grandi and Chicca 2004). In most teleost species, the endocrine cells of the pituitary develop at early larval stages and the detection of hormones by immunocytochemistry suggests that they are functional (Cambre et al. 1990; Power and Canario 1992). However, in zebrafish, salmonids and ayu, somatotrophs, lactotrophs and somatolactotrophs develop prior to hatching (Herzog et al. 2003; Sbrogna et al. 2003). A number of studies also indicate that the apparent activity of various endocrine cells changes with different life stages (Cambre et al. 1990; Power 1992). The roles of GH, PRL and SL, in the regulation of early fish development, remain to be established. No reports are available which demonstrate that unfertilized fish eggs contain maternally derived pituitary hormones, although several studies have shown that the mRNA for these hormone genes are present in eggs (Santos et al. 2003).

In the present study, the ontogeny of two principal endocrine systems, the pituitary and thyroid, in relation to overall larval development, is studied for the first time in larval and juvenile Atlantic halibut. Thyroid gland ontogeny is presented along with the levels of whole body $\mathrm{T}_{3}$ and $\mathrm{T}_{4}$ content. In addition, the ontogeny of the pituitary gland and the endocrine cells producing $\mathrm{GH}$, PRL, SL and TSH is described.

\section{Materials and methods}

\section{Larval culture}

The Atlantic halibut larvae used in this study were raised at Fiskeldi Eyjafjarðar Ltd, Iceland. Larvae from the captive broodstock (Björnsson et al. 1998) were raised using standard commercial production routines. Fertilized eggs from several spawning batches were kept in separate open system egg incubators for about 14 days. The eggs were then collected from several egg incubators over a period of 5-6 days and moved to a conical bottom up-welling larval rearing incubator. When about $50 \%$ of the eggs had hatched, the larvae in the incubator were regarded to be at the age of zero $\mathrm{D}^{\circ}$. However, as hatching is not a fully synchronized event, some degree of age variation (maximally $30 \mathrm{D}^{\circ}$ ) may have occurred within the larval groups sampled. Yolk sack larvae were raised in full-strength seawater at a temperature of $5.2^{\circ} \mathrm{C}$. After the absorption of the yolk sack, the larvae were moved to 1001 , round polyethylene start-feeding tanks, with a circular water flow and a central standpipe outlet. In these tanks, the larvae were reared at $10-11^{\circ} \mathrm{C}$, under constant light conditions ( $24 \mathrm{~h}$ light). The larvae were fed live Artemia (Olsen et al. 1999) two times a day. Algae (Isocrysis sp.) were added just before feeding and the number of algae in the tanks was 150,000 cells $\mathrm{ml}^{-1}$. Dead larvae were siphoned from the tanks each day and the mortality in each tank registered.

\section{Sampling}

The larvae were sampled with a dip-net at regular intervals, from the age of $22 \mathrm{D}^{\circ}$ through to the end of metamorphosis, with the final sampling taking place at $964 \mathrm{D}^{\circ}$. The larvae were sampled in two series over 2 years. In the first set, larvae originating from a single hatching silo were sampled at 13 time-points from hatch to juvenile (at $88,135,187,241,308,360,445,498,606$, $670,721,784$ and $856 \mathrm{D}^{\circ}$ ). The second sampling series was more targeted. It originated from two different hatching silos and had a total of 22 sampling timepoints: 14 samplings from the first silo (at 22, 101, 121, $142,172,188,198,218,243,332,374,537,558$ and 
$570 \mathrm{D}^{\circ}$ ) and eight consecutive samplings from the second silo (at 602, 610,645, 667, 700, 732, 807 and $964 \mathrm{D}^{\circ}$ ). For analysis of the data, the two sampling series were combined. At each sampling time, the samples were collected and preserved in three ways: frozen on dry ice for radioimmunoassay (RIA), fixed in a sublimated Bouin-Hollande solution for conventional histology examination, and fixed in paraformaldehyde (4\% PFA) for immunohistochemistry (IHC) and in situ hybridization (ISH).

In addition to the above listed samplings, larvae were sampled from first feeding through metamorphosis and staged according to a scheme recently developed for Atlantic halibut larvae (Saele et al. 2004). Briefly, there are six larval stages, ranging from first feeding (stage 5) through metamorphosis and settlement (juveniles). Larvae are staged on the basis of morphological development and cranial ossification, and there is a significant correlation between the developmental stages and myotome height (MH) (Saele et al. 2004). In the current study, the larvae were staged according to MH. The relationships between developmental stages, $\mathrm{D}^{\circ}, \mathrm{MH}$ and days after start of first feeding are shown in Table 1.

\section{Tissue processing}

The larvae were fixed in Bouin-Hollande for $48 \mathrm{~h}$ or in PFA overnight at $4{ }^{\circ} \mathrm{C}$ and decalcified in EDTA pH 8, when necessary. The larvae were embedded in paraffin by dehydration through a graded ethanol series from 80 to $100 \%$, saturated in xylene $(100 \%)$ and impregnated and embedded in Histosec (Merk, Darmstadt, Germany). Serial sections $(5-7 \mu \mathrm{m})$ of embedded larvae were mounted on glass slides coated with poly-L-lysine (Sigma-Aldrich, Madrid, Spain; Stockholm, Sweden) for histology and IHC and APES (Sigma-Aldrich) for ISH. The sections were dried at $37^{\circ} \mathrm{C}$ for at least $24 \mathrm{~h}$, cooled for $30 \mathrm{~min}$ and, thereafter, stored or stained.

\section{Histology}

The larval sections were dewaxed and rehydrated through graded alcohols. Mercury was removed from the tissues fixed in the Bouin-Hollande fixative by immersing the slides in iodine $(1 \%)$ in $70 \%$ alcohol, followed by sodium thiosulfate (about $5 \%$ ) and then rinsing in tap water and distilled water. In order to visualize the thyroid gland development, the sectioned larvae were stained using Cleveland-Wolfe trichrome staining (Cleveland and Wolfe 1932). The tissue sections were stained in Erlich's haematoxylin for $5 \mathrm{~min}$, then "blued" by a short immersion in alkaline alcohol to stain nuclei, rinsed in tap water and distilled water, followed by staining in $1 \%$ aqueous erythrosine for 5 min. Subsequently, tissue sections were rinsed in tap water and distilled water and then stained for 8-10 $\mathrm{s}$ in Orange $\mathrm{G}(2 \%$ in $1 \%$ phosphotungstic acid), then rapidly rinsed and stained in Aniline blue $(0.25 \%$ aqueous, acidified to $\mathrm{pH} 3-4$ ) for $1.5 \mathrm{~min}$. Finally, the sections were rapidly rinsed in two changes absolute alcohol, followed by xylene, and mounted in DPX mountant for microscopy; a mixture of the plasticizer distyrene and xylene. When the thyroid follicles, located in the lower jaw at the insertion of the gill bars into the pharynx, are examined, the colloid should be stained brightly red, while the epithelial cells of the follicle should be stained blue or purple.

\section{Immunocytochemistry}

Somatotrophs, lactotrophs, somatolactotrophs and thyrotrophs were investigated by staining serial tissue sections with homologous or heterologous hormonespecific antibodies. Somatotrophs were detected using anti-halibut GH $(1: 10,000)$, raised in rabbits, against native halibut $\mathrm{GH}$. The antiserum specificity has previously been characterized by RIA (Einarsdóttir et al. 2002). For the detection of lactotrophs and somatolactotrophs, anti-chum salmon PRL $(1: 1,000)$ and antiseabream SL $(1: 1,500)$, which have been previously characterized (Power and Canario 1992), were used. Thyrotrophs were detected using anti-human TSH-h sera (1:500, National Institute of Diabetes and Digestive and Kidney Diseases (NIDDK), National Institutes of Health (NIH), Bethesda, MD, USA), the specificity of which has been previously characterized in halibut (Weltzien et al. 2003). Based on observations of stained adult halibut pituitaries and results from a previous study (Weltzien et al. 2003), it is confirmed that all antisera utilized bind to the appropriate halibut cell type. To further confirm PRL and SL antisera specificity, sections from adult halibut pituitaries have been stained with the antisera preab-
Table 1 The relationship between the stages of Atlantic halibut (Hippoglossus hippoglossus) larvae and juveniles, as defined by Saele et al. (2004), myotome height, day-degrees and days after commencement of feeding

\begin{tabular}{llll}
\hline Stage nos. & $\begin{array}{l}\text { Myotome } \\
\text { height }(\mathrm{mm})\end{array}$ & $\begin{array}{l}\mathrm{D}^{\circ} \text { (accumulated } \\
\text { daily temperature } \\
\left({ }^{\circ} \mathrm{C}\right) \text { from hatching) }\end{array}$ & $\begin{array}{l}\text { Days after } \\
\text { commencement } \\
\text { of feeding }\end{array}$ \\
\hline 5 & $<2.0$ & $260-430$ & $1-17$ \\
6 & $2.0-2.9$ & $430-530$ & $18-27$ \\
7 & $2.9-4.7$ & $530-600$ & $28-33$ \\
8 & $4.7-5.6$ & $600-650$ & $34-38$ \\
9 & $5.7-8.4$ & $650-800$ & $39-49$ \\
Juveniles & $>8.4$ & $>800$ & $>50$ \\
\hline
\end{tabular}


sorbed with the antigen. Non-specific staining was not seen (data not shown).

Dewaxed and rehydrated larval sections were used for the IHC detection of endocrine cells. Mercury was removed as outlined above. The sections were incubated overnight at $4^{\circ} \mathrm{C}$ with the primary antiserum, diluted in a PBS buffer $\mathrm{pH} 7.4$ containing $\lambda$-carrageenan and $0.5 \%$ Triton X-100. The sections were then incubated for 45 min with the secondary antibody, an anti-rabbit Ig peroxidase conjugate (Sigma-Aldrich) diluted 1:50 in Tris/HCl. Color was developed using diaminobenzidinetetrahydrochloride (Sigma-Aldrich) as the chromagen. The sections were counterstained with Harris Haematoxylin, dehydrated, cleared in xylene and mounted in DPX. Control reactions, in which primary or secondary antisera were omitted from the staining procedure or substituted by pre-immune sera, were negative.

In situ hybridization

Digoxygenin-labelled riboprobes for GH, PRL and SL were prepared by the in vitro transcription of plasmid DNA, containing full-length cDNAs encoding the complete sequence of seabream GH (GenBank accession no. AY038038), PRL (GenBank accession no. AF060541) and SL (GenBank accession no. L49205). The DNA was purified, linearized with EcoRI (Promega, Madison, WI, USA) at $37^{\circ} \mathrm{C}$ during $1.5 \mathrm{~h}$, and then purified and resuspended in $20 \mu \mathrm{l}$ sterile water. The riboprobes were synthesized using linearized DNA as a template and $20 \mathrm{U}$ of T7 RNA polymerase in a transcription buffer (Promega) with $1 \mu \mathrm{l}$ of digoxygeninRNA labeling mix (Roche Diagnostics, Mannheim, Germany), for $1.5 \mathrm{~h}$ at $37^{\circ} \mathrm{C}$. The reaction was stopped with $2 \mu \mathrm{l}$ of $0.2 \mathrm{M}$ EDTA and the quality and quantity of the riboprobe generated checked by fractionation of the reaction products on an agarose gel $(1.5 \%)$.

Sagittal sections of the larvae were pre-hybridized at $58^{\circ} \mathrm{C}$ for $2 \mathrm{~h}$ in a hybridization solution $(50 \%$ formamide, $4 \times$ SSC, $0.1 \%$ torula RNA, $0.01 \%$ Heparin, $1 \times$ Denhart's, $0.1 \%$ Tween $20,0.04 \%$ CHAPS). Hybridization was performed overnight in the same solution, containing the riboprobe $\left(2 \mu \mathrm{g} \mu \mathrm{l}^{-1}\right)$, at $58^{\circ} \mathrm{C}$. To remove non-specifically bound probes, high stringency washes were done at $58^{\circ} \mathrm{C}$ with $2 \times \mathrm{SSC}(2 \times 5 \mathrm{~min}), 1 \times \mathrm{SSC}$ $(5 \mathrm{~min})$. The hybridized riboprobes were detected by anti-digoxigenin-AP Fab fragments (1:600, Roche Diagnostics) and color developed at $37^{\circ} \mathrm{C}$ for $1 \mathrm{~h}$, using the chromagens NBT (4-nitroblue tetrazolium chloride) and BCIP (5-bromo-4-chloro 3-indolylphosphate) as enzymatic substrates. The staining reaction was stopped with $1 \times$ PBS and the sections were fixed for $15 \mathrm{~min}$ with $4 \%$ PFA at room temperature, rinsed with $1 \times \mathrm{PBS}$ and distilled water, and mounted in glycerol gelatin.

Control experiments, performed by treating the samples with Rnase, prior to hybridization with the riboprobe and/or by omitting riboprobe from the reaction, were negative.
Stained sections from the IHC and ISH were analyzed using a microscope (Olympus $\mathrm{BH} 2$ ) coupled to a digital camera (Olympus DP11) and linked to a computer for digital image analysis.

\section{Thyroid hormone radioimmunoassay}

The $T_{4}$ and $T_{3}$ contents in whole larval extracts were assessed by RIA. Pools of frozen larvae (yolk sack, stages 5-8) or individual larvae were extracted in methanol, reextracted in $50 \mu \mathrm{l}$ methanol, $200 \mu \mathrm{l}$ chloroform and $100 \mu \mathrm{l}$ barbital buffer, and centrifuged $\left(3,000 \mathrm{~g}\right.$ for $30 \mathrm{~min}$ at $\left.4^{\circ} \mathrm{C}\right)$. The upper phase was then removed, lyophilized, reconstituted in an assay buffer and assayed.

Assays for both $T_{3}$ and $T_{4}$ were performed using a double-antibody method under equilibrium conditions. The standard curves were prepared with $\mathrm{T}_{4}$ or $\mathrm{T}_{3}$ standards (Sigma-Aldrich) dissolved in $0.1 \mathrm{~N} \mathrm{NaOH}$ and diluted to appropriate concentrations in an assay buffer. $\mathrm{T}_{3}$ and $\mathrm{T}_{4}$ assays were conducted in a barbital buffer (0.07 M, pH 8.6) and a Tris buffer (0.1 M, pH 7.4), respectively, and contained $0.1 \% \mathrm{BSA}$ and $0.1 \%$ sodium azide. In both cases, either $100 \mu \mathrm{l}$ of standard or larval extract was added. The total assay volume was $400 \mu \mathrm{l}$ and included $100 \mu \mathrm{l}$ of ${ }^{125} \mathrm{I}_{-} \mathrm{T}_{3}$ (Amersham Biosciences, Buckinghamshire, UK) or ${ }^{125} \mathrm{I}_{-} \mathrm{T}_{4}$ and $100 \mu \mathrm{l} \mathrm{T}_{3}$ $(1: 16,000)$ or $T_{4}$ antisera $(1: 5,000$, both from Sigma-Aldrich). Antisera were added to all tubes except those used to determine total count (cpm) and non-specific binding. In both the $\mathrm{T}_{3}$ and the $\mathrm{T}_{4}$ assay, the tubes were incubated for $16-24 \mathrm{~h}$ at $4^{\circ} \mathrm{C}$ and, subsequently, the free hormone was separated from the bound hormone, using precipitation with a secondary antibody (Rotllant et al. 2003).

The RIA for $T_{4}$ and $T_{3}$ were highly specific, with less than $0.01 \%$ cross-reactivity in the assays for each other or for related molecules (diiodo-L-thyronine, diiodo-Ltyrosine, monoiodo-L-tyrosine, reverse T3, D-thyroxine and triiodo-D-thyronine). The intra-assay coefficient of variation was $<5.6 \%$ and the inter-assay variation, measured in duplicate on 15 occasions, was $<7 \%$. The efficiency of the TH tissue extraction method was $>78 \%$ and the determination of THs in serial dilutions of larval extracts (stage 9) gave a curve parallel to the standard curve.

\section{Results}

\section{Histological development of TH follicles}

In the halibut as in most other teleosts, histological studies show the thyroid tissue to be unencapsulated and scattered, primarily in the pharynx, at the insertion of the branchial arches. The ontogeny of halibut larvae thyroid follicles is described in Fig. 1 and exemplified in Fig. 2a, b, c, d, e, f, g, h, i and j. The first sporadic 
thyroid follicles are observed in yolk sack larvae sampled at $142 \mathrm{D}^{\circ}$ (27 days post-hatch). The follicles have a characteristic appearance and are composed of a colloidfilled centre surrounded by a unicellular flattened epithelial layer (Fig. 2a, b). The morphology of the follicles at this stage indicates that they are relatively inactive. In larvae sampled from 218 to $243 \mathrm{D}^{\circ}$, prior to complete yolk sack absorption, thyroid follicles are found to be more numerous and, on average, a few small thyroid follicles are present per section. In larvae sampled from 308 to $360 \mathrm{D}^{\circ}$, when the larvae have already started feeding, the follicles are more numerous, with 3-12 follicles per section (Fig. 2c, d). Following the yolk sack period, instances are found where the colloid is absent from follicles (Fig. 2e), suggesting increased thyroid activity. Furthermore, the number and size of the thyroid follicles and their apparent activity continuously increase until the start of metamorphosis (around $600 \mathrm{D}^{\circ}$ ), when there are more than 12 follicles per section (Fig. 2g). A large number of the follicles lack colloid and are bounded by a columnar epithelial layer, which is indicative of high thyroid activity (Fig. 2g, h). During metamorphosis, in all the larvae examined, the thyroid follicles were numerous and their high activity was supported by the presence of vesicles in the periphery of the colloid (Fig. 2i, j).

Larval content of $\mathrm{T}_{3}$ and $\mathrm{T}_{4}$

The whole larval content of the THs during Atlantic halibut development is variable but the pattern of variation appears to accompany significant larval transitions: yolk sack to first feeding and larval/juvenile transition (Fig. 3). In yolk sack larvae up to $218 \mathrm{D}^{\circ}$, the content of $\mathrm{T}_{4}$ is fairly constant, at ca $10 \mathrm{pg} \mathrm{mg}^{-1}$ wet weight $(n=3)$, and is presumably derived largely from maternal hormones deposited in the egg prior to spawning. At first feeding, i.e., stage 5, there is a drop in the $\mathrm{T}_{4}$ content, to ca $5 \mathrm{pg} \mathrm{mg}^{-1}$ wet weight $(n=3)$, which is coincident with the absorption of the yolk sack and the dependence of the larvae on the production of

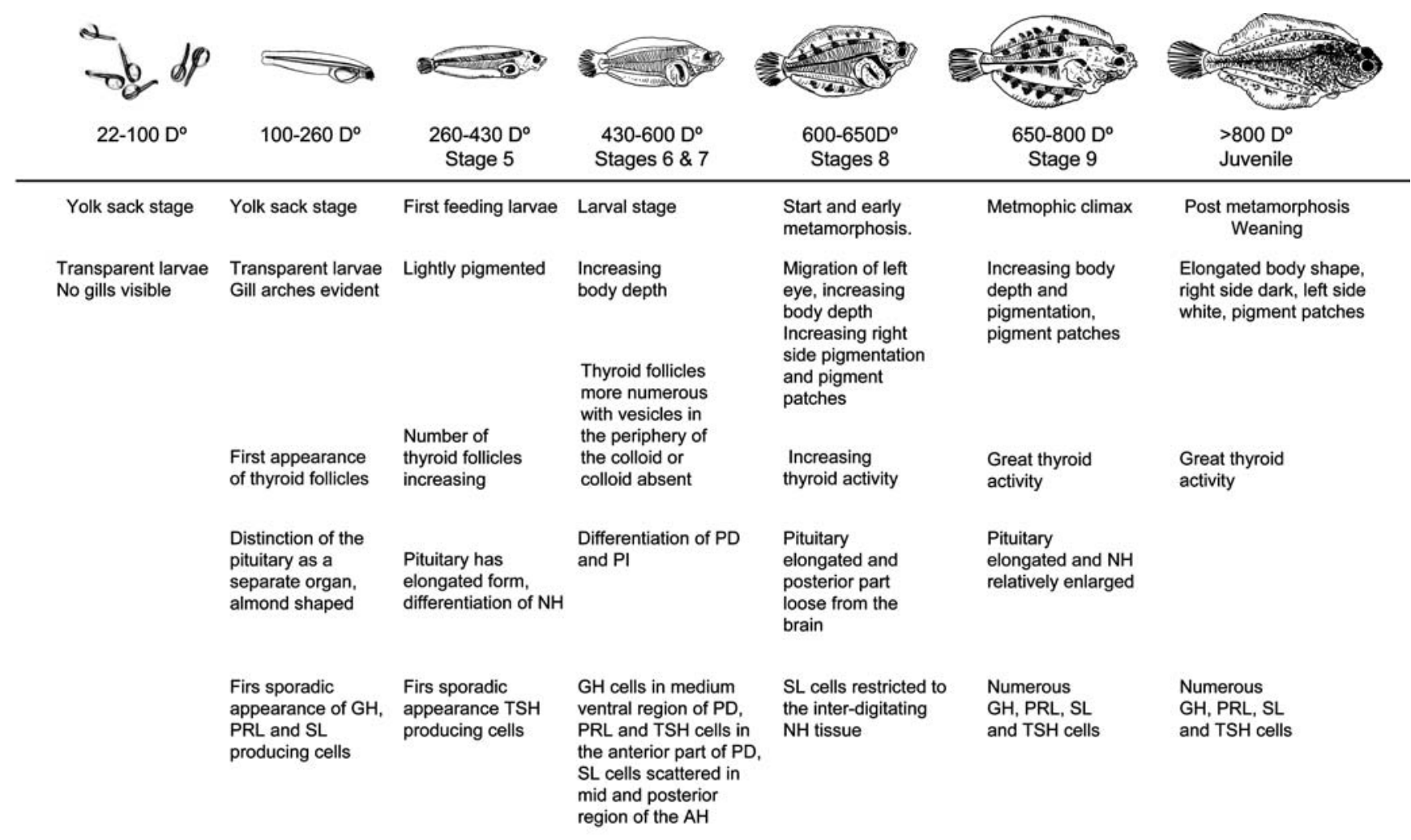
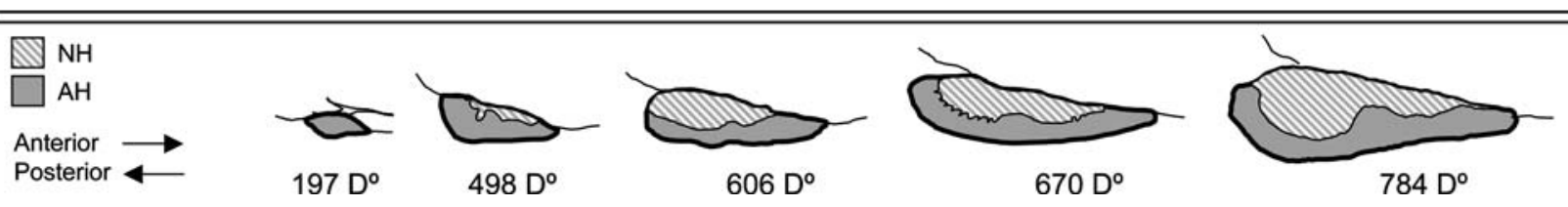

Fig. 1 Gross morphology of Atlantic halibut (Hippoglossus hippoglossus) and its pituitary and thyroid follicles from the yolk sack to the juvenile stage. Thyroid activity and the distribution of somatotrophs, lactotrophs, somatolactotrophs and thyrotrophs in the pituitary, are mapped throughout larval development. $D^{\circ}$ day-

degrees (accumulated daily temperature $\left({ }^{\circ} \mathrm{C}\right)$ from hatching), $G H$ growth hormone, $P R L$ prolactin, $S L$ somatolactin, $T S H$ thyroid stimulating hormone, $P D$ pars distalis, $P I$ pars intermedia, $N H$ neurohypophysis, $A H$ adenohypophysis 
Fig. 2 Cleveland-Wolfe trichrome staining on sagittal sections of different developmental stages of Atlantic halibut (Hippoglossus hippoglossus) larvae, showing the ontogeny of thyroid follicles. (a) Yolk sack stage larvae; (b) detail of a thyroid follicle at the yolk sack stage; (c) the first feeding (stage 5); (d) detail of a thyroid follicle at stage 5; (e) larval stage (stage 6); (f) detail of a thyroid follicle at stage $6 ;(\mathrm{g})$ start of metamorphosis (stage 8); (h) detail of a thyroid follicle at stage 8 ; (i) the metamorphic climax (stage 9); (j) detail of a thyroid follicle at stage 9 , where the presence of vesicles $(v)$ at the periphery of the colloid $(c)$ in some follicles is evident, epithelial cell layer (e). Scale bars indicate $20 \mu \mathrm{m}$
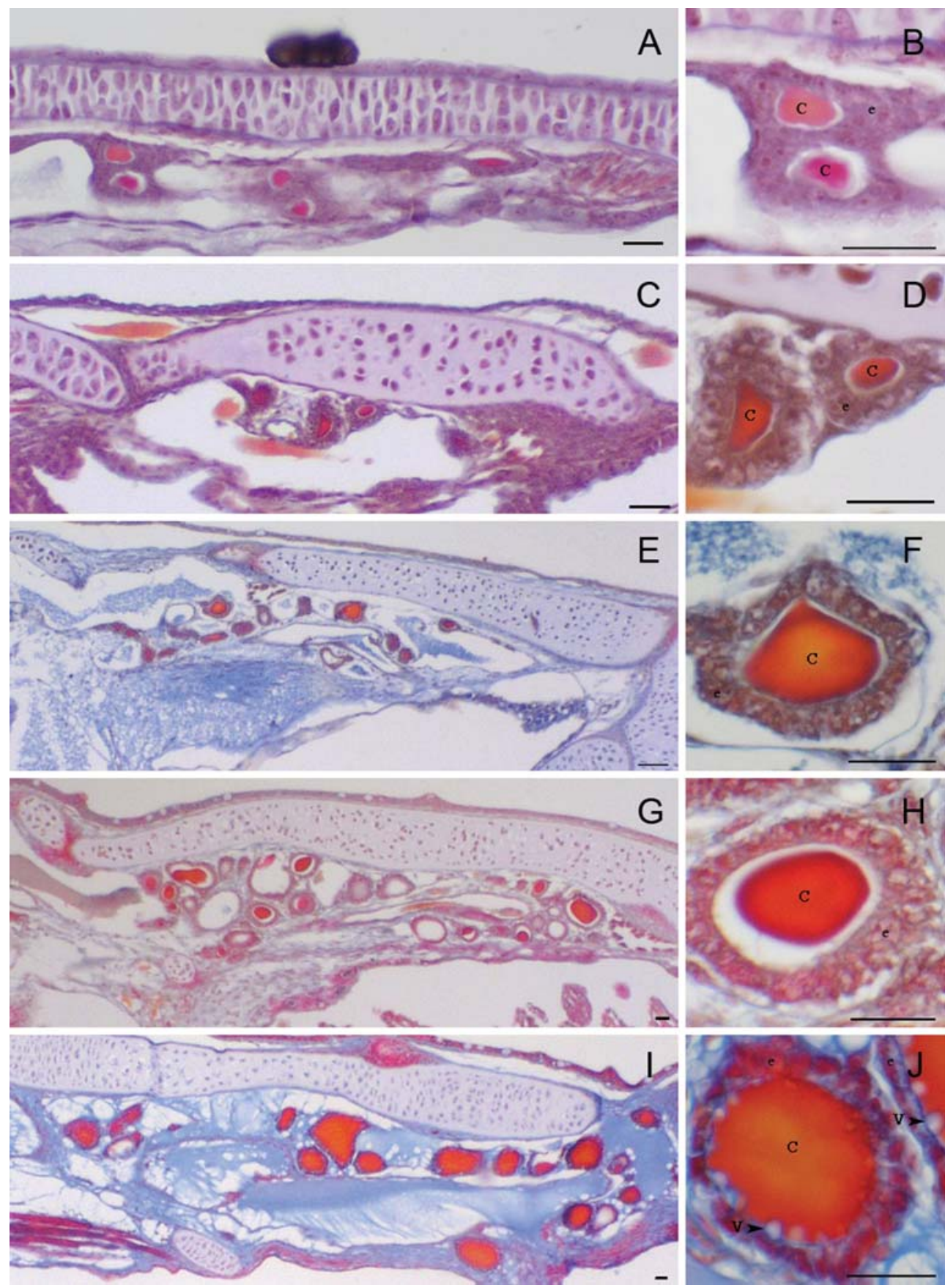

endogenous THs from the proliferating thyroid follicles. The $\mathrm{T}_{4}$ content of the larvae continues to decline until stage 8 , the start of metamorphosis, when there is an abrupt increase, up to ca $4.5 \mathrm{pg} \mathrm{mg}^{-1}$ wet weight $(n=3)$. Stage 9, the metamorphic climax, is accompanied by a reduction in the measurable $T_{4}$. The larval $T_{3}$ content studied in all the stages of development is significantly lower than that of $\mathrm{T}_{4}$ and is, on an average, $<1 \mathrm{pg} \mathrm{mg}^{-1}$ wet tissue. Moreover, the amplitude of $\mathrm{T}_{3}$ variation during Atlantic halibut development is much smaller than that of $T_{4}$. The concentration of $T_{3}$ in the yolk sack larvae is significantly lower than that of $\mathrm{T}_{4} \mathrm{ca}$
$1.25 \mathrm{pg} \mathrm{mg}^{-1}$ wet weight $(n=3)$, the transition to the first feeding larvae (stage 5) which are presumably dependent on endogenous hormone is accompanied by a further reduction in $\mathrm{T}_{3}$. A small peak of $\mathrm{T}_{3}$ coincides with the start of metamorphosis (1.5 $\mathrm{pg} \mathrm{mg}^{-1}$ wet tissue) at $610 \mathrm{D}^{\circ}$ and, unlike $\mathrm{T}_{4}$, at the climax of metamorphosis (i.e., stage 9), $T_{3}$ is maintained at levels similar to those present at the start of metamorphosis. It would appear that the change in the whole larval THs, particularly $\mathrm{T}_{4}$, the principal product of the thyroid follicle, approximately correlates with the changing cycle of activity of the thyroid follicles, as detected by histology. 
Fig. 3 Whole larval content of $\mathrm{T}_{4}$ and $\mathrm{T}_{3}$ in yolk sack larvae and stage 5 through to 9 of Atlantic halibut. At least three independent samples were used for each age group. Owing to the small size of the larvae, samples were composed of pools of larvae from the yolk sack through to stage 8 , after which individual larvae were utilized. Data are presented as mean \pm standard deviation. Note the elevated concentration of THs in the yolk sack larvae, which is presumably of maternal origin as infrequent thyroid follicles are first detected at $142 \mathrm{D}^{\circ}$

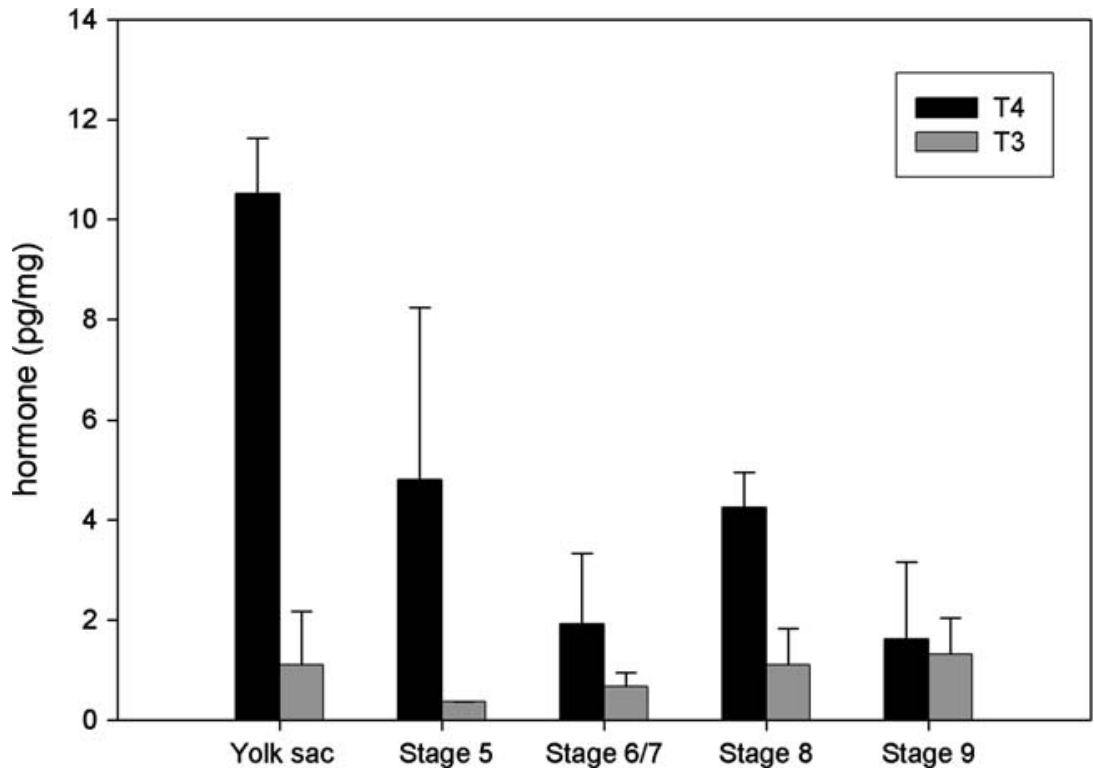

Ontogeny of the pituitary gland

The main developmental features of the pituitary and endocrine cells are shown and briefly described in Fig. 1. The pituitary gland in halibut larvae can first be discerned at $121 \mathrm{D}^{\circ}$ (around 23 days post-hatch) as a small cluster of cells at the base of the brain, near the optic chiasm and third ventricle. At this point, the brain is symmetrical and the pituitary lies mid-line. Subsequently, at $142 \mathrm{D}^{\circ}$, the pituitary gland is larger and almond-shaped, but is still closely associated with the brain and is not yet distinguishable as a separate organ, until around $195 \mathrm{D}^{\circ}$ (Fig. 1). At $308 \mathrm{D}^{\circ}$ (52 days posthatch), the pituitary becomes more elongated and the initial differentiation of the $\mathrm{NH}$ is observed at $360 \mathrm{D}^{\circ}$ (around 70 days post-hatch, stage 5). In feeding halibut larvae, from $360 \mathrm{D}^{\circ}$ to the start of metamorphosis (around $600 \mathrm{D}^{\circ}$, stage 7, Fig. 1), a clear differentiation of the pituitary gland into the PD, PI and NH occurs. Up to this point, both the brain and the pituitary are bilaterally symmetrical and the pituitary occupies a midline position in relation to the brain.

Associated with the start of metamorphosis (around $600 \mathrm{D}^{\circ}$, stage 7) through to metamorphic climax, there is a gradual change in the disposition of the brain, as a consequence of the migration of the left eye, although the relationship of the pituitary with the hypothalamus is unaltered.

\section{Ontogeny of GH, PRL, SL and TSH cells}

Somatotrophs are first identified in larvae, sampled at $121 \mathrm{D}^{\circ}$ (23 days post-hatch), as occasional brownstained cells at the base of the brain. By $142 \mathrm{D}^{\circ}$, when the pituitary gland is almond-like in shape, the somatotrophs increase in number and are scattered in the anterior region. The grouping of the somatotrophs into a cluster occurs just prior to first feeding in larvae, sampled at $172 \mathrm{D}^{\circ}$ (around 33 days post-hatch), at which point the somatotrophs start to occupy a central position in the pituitary gland. In larvae sampled at $308 \mathrm{D}^{\circ}$ and at stage 5, when the pituitary has become more elongated, numerous somatotrophs are present and occupy the medium-ventral region of the PD (Fig. 4a). After differentiation of the pituitary is seen clearly (around $360 \mathrm{D}^{\circ}$ and at stage 5) and throughout development and metamorphic changes (metamorphic climax $650-800 \mathrm{D}^{\circ}$, stage 9, Fig. 1), a strong immunoreaction is evident in the somatotrophs that occupy the PPD and they have an appearance similar to those in the juvenile and adult fish (Fig. 4c).

The development of lactotrophs appears to be delayed, when compared with somatotrophs, with the first, weakly staining lactotrophs found at approximately $134 \mathrm{D}^{\circ}$ (about 25 days post-hatch). By $142 \mathrm{D}^{\circ}$, more lactotrophs are detected and are scattered in a region anterior to the somatotrophs. The lactotrophs are oval in shape and contain intensely staining cytoplasm. Similar to what is observed for the somatotrophs, by $360 \mathrm{D}^{\circ}$, i.e., at stage 5 , when the pituitary has differentiated into the main regions, the lactotrophs are numerous and occupy the most anterior part of the pituitary gland (Fig. 4e). From then on there is a successive increase in the number of lactotrophs that are oval and with abundant cytoplasm. By $784 \mathrm{D}^{\circ}$, at the climax of metamorphosis, the lactotrophs are numerous and restricted to the RPD (Fig. $4 \mathrm{~g}$ ).

Somatolactotrophs are first detected, infrequently and with a weak stain, at $121 \mathrm{D}^{\circ}$ (around 23 days after hatch). By $142 \mathrm{D}^{\circ}$, more somatolactotrophs are detected; they are large and round in shape, with strongly staining cytoplasm, and are scattered throughout the pituitary gland. The abundance and disposition of the somatolactotrophs, thereafter, follows the development 
Fig. 4 Sagittal sections of Atlantic halibut larvae demonstrating the ontogeny of the principal endocrine cells in the pituitary gland.

Somatotrophs in Atlantic halibut stained by immunohistochemistry (IHC) at (a) the first feeding (stage 5) and (c) the metamorphic climax (stage 9), and stained by in situ hybridization (ISH) at (b) stage 5 and (d) stage 9. Note the abundant cells localized in the pars distalis. Lactotrophs (PRL) stained by IHC at (e) stage 5 and (g) stage 9 , and stained by ISH at (f) stage 5 and (h) stage 9. The reactive cells are restricted to the rostral pars distalis. Somatolactotrophs (SL) stained by IHC in Atlantic halibut larvae at stage 5 (i) and stage $9(\mathbf{k})$ and by ISH at stage 5 (j) and stage 9 (I). Note the abundant cells in the pars intermedia. Thyrotrophs (TSH) stained by IHC in Atlantic halibut larvae at stage $5(\mathbf{m})$ and stage $9(\mathbf{n})$. Note that TSH cells are scarce (arrowhead in $\mathbf{m}$ ) in stage 5 larvae but by stage 9 a strong reaction is detected adjacent to the rostral pars distalis. Scale bars indicate $20 \mu \mathrm{m}$
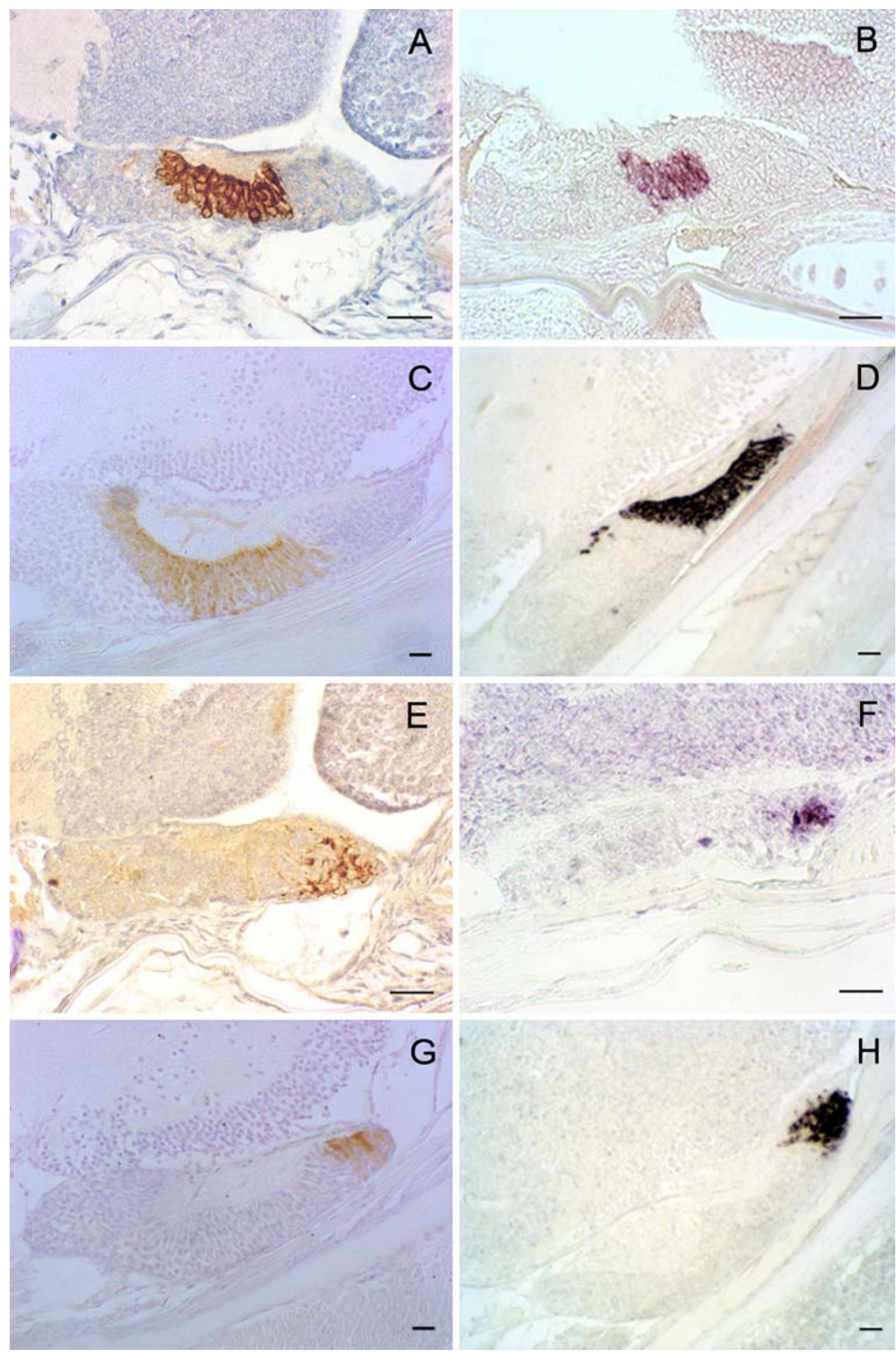

of the pituitary gland. Initially, abundant intensely stained cells are scattered throughout the mid and posterior region of the developing pituitary gland. As the intermediate lobe develops $\left(260-430 \mathrm{D}^{\circ}\right.$, stage 5), the somatolactotrophs become restricted to this region and are very abundant around the interdigitating neurohypophysial tissue (Fig. 4i). At the climax of metamor- phosis, at $784 \mathrm{D}^{\circ}$, the somatolactotrophs are far more numerous than the somatotrophs, the lactotrophs or thyrotrophs and have an intensely stained cytoplasm (stage 9, Fig. 4k).

Thyrotrophs are the last of the endocrine cells studied to develop and scarce, weakly immunoreactive thyrotrophs are first detected (Fig. $4 \mathrm{~m}$ ) only in stage 5. The 
Fig. 4 (Contd.)
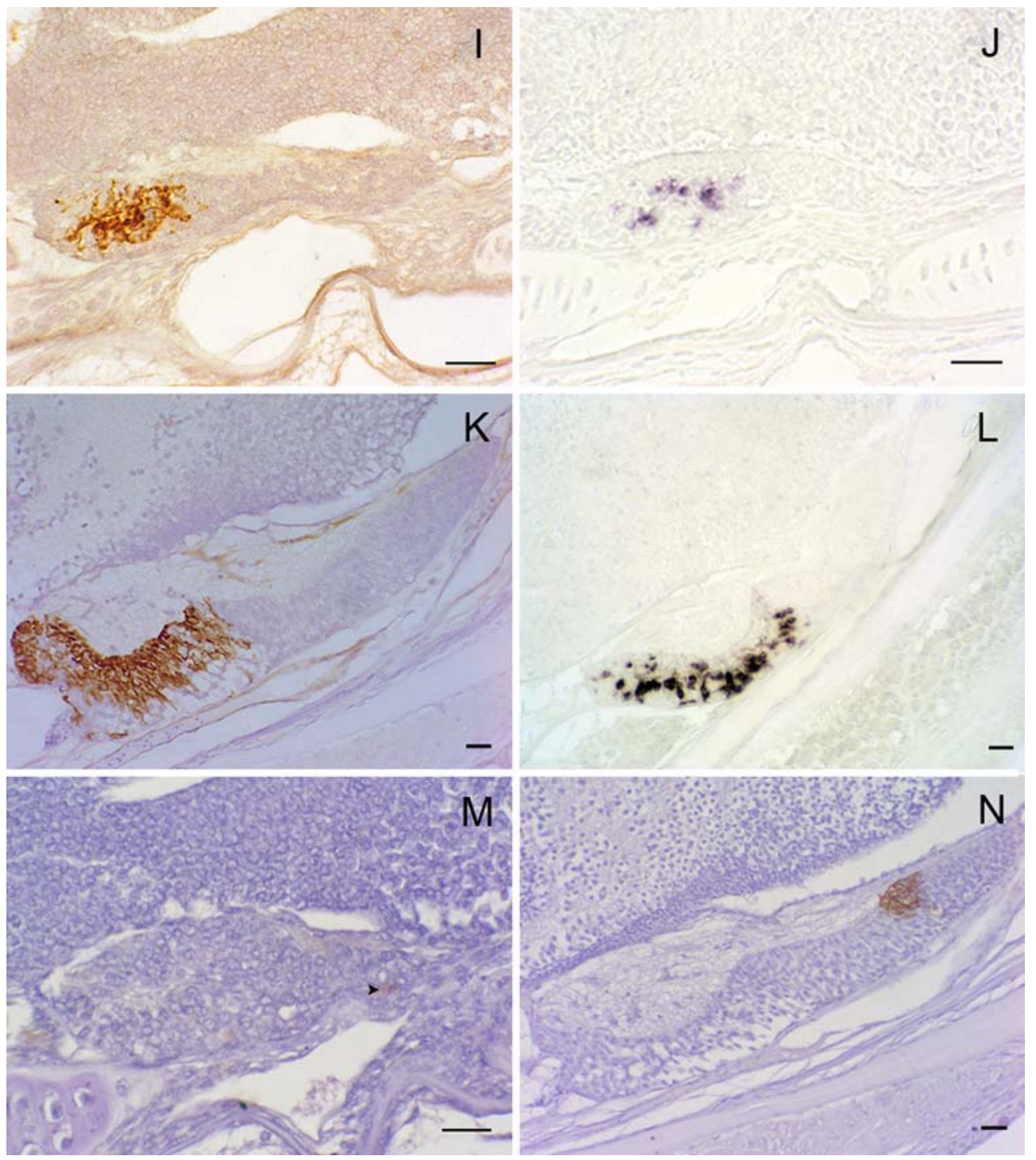

cells are small, contain scarce cytoplasm and appear to be localized in the RPD. As the Atlantic halibut develops the thyrotrophs become more abundant and, prior to (i.e., stage 8) and at the climax of metamorphosis (i.e., stage 9 , Fig. $4 \mathrm{n})$ a group of intensely staining thyrotrophs are readily detected adjacent to the RPD.

ISH results show the ontogeny and pattern of distribution of the mRNA for the hormones analyzed, to coincide with their respective protein distribution as established by the IHC. Generally, it is possible to detect mRNA for the target genes slightly prior to the detection of the protein by IHC. The abundance of hormone transcripts (assessed by signal intensity) detected in the pituitary somatotrophs (Fig. 4b, d), lactotrophs (Fig. 4f, h) and somatolactotrophs (Fig. 4j, l) is always much higher in the stage 9 Atlantic halibut larvae, when compared with earlier larval stages. TSH transcripts have not been detected during pituitary ontogeny of the Atlantic halibut as no probe is available.

\section{Discussion}

Thyroid hormones are found in the eggs and larvae of a number of different fish species (Tagawa et al. 1990a, b; Power et al. 2001) and the present study indicates that the Atlantic halibut is no exception. As has been demonstrated for other fish species, it can be assumed that the halibut egg/yolk sack carries a maternal source of THs, as detectable levels of THs are found in the halibut larvae prior to $142 \mathrm{D}^{\circ}$, when a few sporadic thyroid gland follicles first appear. The potential role of THs in early fish development is suggested from studies in which THs have been administered and shown to accelerate development and improve survival in round fish (Brown et al. 1988; Brown and Kim 1995; de Jesus et al. 1998). In addition, the inhibition of $\mathrm{TH}$ synthesis suggests that THs play an important role in fin and scale development in zebrafish larvae (Brown 1997). The appearance of thyroid follicles $\left(142 \mathrm{D}^{\circ}\right)$ and the measurable content of 
THs in early yolk sack larvae of Atlantic halibut suggest that they could have a similar role in this species.

The biological actions of THs are brought about by their binding to thyroid hormone receptors (TRs), which are members of the nuclear receptor super-family (Mangelsdorf et al. 1995; Wu and Koenig 2000). Two TR isoforms have been identified in most vertebrates and are designated TR- $\alpha$ and TR- $\beta$. THs bind to both TR isoforms and regulate the transcription of target genes (Brent 1994). In order for THs to be active, the receptors must also be present. TR- $\alpha$ has been isolated in the Atlantic halibut and its expression in embryos and larvae has been studied (Llewellyn et al. 1999). TR- $\alpha$ was found to be significantly upregulated in post-hatch larvae at $20 \mathrm{D}^{\circ}$ and in all subsequent stages (Llewellyn et al. 1999). These data, taken together with the results of the present study, indicate that all elements necessary for $\mathrm{TH}$ activity are present early in the larval development of Atlantic halibut and, thus, support the notion that these hormones may have a role in regulating early developmental processes. However, it remains to be established if TR- $\beta$ is also expressed in Atlantic halibut larvae and the nature of the processes that TR- $\alpha$ and TR- $\beta$ regulate.

The best-studied role for THs during development is during amphibian metamorphosis, where these hormones have been demonstrated to play a crucial role in driving the metamorphic process (Shi et al. 1996; Oppenheimer and Schwartz 1997; Koibuchi and Chin 2000). In the Japanese flounder, metamorphosis appears to be regulated by the THs in a way comparable to that in amphibians (Inui and Miwa 1985). In flounder larvae, TH hormone administration stimulates eye migration, second dorsal fin ray absorption and settling behavior, all features characteristic of flatfish metamorphosis; while the administration of goitogens inhibits these features (Inui and Miwa 1985). Furthermore, exogenous $\mathrm{T}_{4}$ and goitogens clearly exhibit feedback effects on the pituitary-thyroid axis in metamorphosing flounder larvae (Miwa and Inui 1987a). In the present study, the significant increase in larval TH content and the apparent increase in thyroid follicle activity just prior to, and during metamorphosis, suggest that the THs have a similar role in the Atlantic halibut.

The ontogeny of the pituitary gland during larval development has been characterized in a number of different fish species. Despite their differing larval ontogeny, endocrine cells have been reported to first arise in the post-hatch larvae of sea bass, coho salmon (Oncorhynchus kisutch), chum salmon, sea bream, ayu and Japanese eel (Cambre et al. 1990; Power and Canario 1992; Naito et al. 1993; Saga et al. 1999). In a study carried out on several marine species, somatotrophs and lactotrophs have been detected shortly before the end of yolk sack absorption, in species with small pelagic eggs and at hatching, in species with larger demersal eggs and/or ovoviviparous species (Tanaka et al. 1995).
Recent studies on pituitary induction and patterning in zebrafish embryos indicate that, in this species, endocrine cells develop prior to hatch (Herzog et al. 2003; Sbrogna et al. 2003). These studies further demonstrate that the pituitary cells in fish are derived from the anterior neural ridge and move inwards as a consequence of oral cavity formation (Glasgow et al. 1997; Herzog et al. 2003). In the present study, the Atlantic halibut pituitary cell ontogeny is found to be more like that of other temperate species, with endocrine cells being first detected in post-hatch larvae. The differences in pituitary ontogeny between the zebrafish and Atlantic halibut are not surprising, considering the great difference in the duration of the larval phase. In fact, the wide range of developmental patterns of fish makes direct comparison of pituitary ontogeny between species difficult.

The presence of endocrine cells, producing GH, PRL, SL and TSH in the halibut larvae in the early yolk sack phase, and their successive increase in number during larval development suggests that these hormones are important for embryonic and larval development. Nevertheless, the mere demonstration of endocrine cells in the present, as well as in other similar studies on other species, does not constitute a full proof of endocrine regulatory activity, as it is not known if or when these hormones are being released into the circulation.

Little is known about the role of GH and PRL in the early ontogeny of teleost fish. In the freshwater teleost, the American shad embryos, lactotrophs have been implicated in both growth and osmoregulation (LaizCarrion et al. 2003). The role of GH and PRL in developmental processes in flatfish has not been clearly established. It seems probable that there will be an overlapping spectrum of activity with that identified in juveniles and adults. In amphibians, both PRL and GH have been proposed as antimetamorphic hormones, although the available data are contradictory. PRL has been considered a "juvenile hormone", opposing the actions of the THs and, thereby, delaying the time set for metamorphosis (Forsyth and Wallis 2002). This is based on in vivo (Dodd and Dodd 1976) and in vitro (Derby and Etkin 1968; Tata et al. 1991; Takada and Kasai 2003) studies with mammalian PRL. However, this is in contrast with data showing that endogenous PRL plasma levels are low at pre- and prometamorphic stages, rising at the metamorphic climax (Clemons and Nicoll 1977; Yamamoto and Kikuyama 1982). The overexpression of PRL in Xenopus indicates that the hormone does not delay metamorphic climax but produces tailed frogs by specifically inhibiting some, but not all, programs for tail reabsorption (Huang and Brown 2000a). The role of $\mathrm{GH}$ as an antimetamorphic hormone has not been established. In Xenopus, the GH mRNA expression is higher in larval stages than during the metamorphic climax (Buckbinder and Brown 1993) and the overexpression of GH stimulates growth in Xenopus tadpoles (Huang and Brown 2000b). However, GH stimulates the development of certain larval-type skin related features, 
in bullfrog skin (Rana catesbeiana) in vitro, but to a lesser extent than PRL (Takada and Kasai 2003).

In Japanese flounder ( $P$. olivaceus $)$, ovine PRL antagonizes the stimulatory effect of $\mathrm{T}_{3}$ on fin ray shortening in vitro and delays the shortening of dorsal fin rays in vivo in prometamorphic larvae, without notably affecting other metamorphic features; while the GH has no effect (de Jesus et al. 1994). When the pituitary content of PRL and GH was assessed indirectly in Japanese flounder, by measuring lactotrophic and somatotrophic cell volumes, respectively, the pituitary PRL content was found to rise until the start of metamorphosis, decline during the metamorphic climax and rise again after metamorphosis; while the GH content rises steadily throughout larval and juvenile development (Tanaka et al. 1995). Together, these results indicate that the PRL may act as an antimetamorphic hormone in flatfish, similar to that in amphibians, whereas the role of the GH may be restricted to posthatch growth.

The physiological role(s) of SL have yet to be fully elucidated. Recently, in a study on color interfere (ci) mutant medaka, SL has been shown to regulate a certain type of chromatophore (leukophore) proliferation and skin morphogenesis (Fukamachi et al. 2004). These results are notable, since a change in skin coloration is a major part of the Atlantic halibut metamorphosis process and a significant increase in the number of somatolactotrophs were observed from the end of the yolk resorption through metamorphic climax in this study.

The temporal and quantitative appearance of thyrotrophs has previously been implicated as an indicator of the onset and degree of thyroid follicle activity in fish larvae. In the Atlantic halibut there is a remarkable correlation between the appearance of abundant well stained thyrotrophs at stage 8 and the significant increase in thyroid follicle activity, as assessed by histology and RIA data. A similar observation has been made in the Japanese eel (A. japonica), A. obscura and A. bicolor in which TSH immunoreactive cells are first seen just prior to the onset of metamorphosis (Ozaki et al. 2000). In contrast, in the only other Pleuronectiform, the Japanese flounder, in which TSH has been studied it is evident soon after hatching (Miwa and Inui 1987b; Ozaki et al. 2000). It would appear that in the Atlantic halibut the surge in TSH production in stage 8 larvae triggers the increase in thyroid follicle activity, as indicated by the peak in circulating $\mathrm{T}_{4}$, which probably drives metamorphosis. It will clearly be of interest to explore this interaction in more detail.

In conclusion, the present data on thyroid gland ontology, its apparent activity, and changes in the TH content, are in full agreement with the notion that THs play a significant role in the metamorphic process of Atlantic halibut. Similarly, ontogeny of the pituitary gland and the proliferation of somatotrophs, lactotrophs and somatolactotrophs, during larval development, has established a time-frame for when these hormones could start to exert physiological effects. Given the descriptive nature of the present study, the observed changes in endocrinology and morphology during larval development and metamorphosis can only be seen as correlative, and any discussion on functional relationships is speculative. However, the observations made in this study should help define hypotheses and experimental approaches, e.g., using agonist/antagonist treatments in vivo or in vitro. Further, studies on the tissue distribution of hormone receptors and other molecules important for mediating hormone action will help elucidate the detailed regulatory role of the pituitary and the THs in flatfish metamorphosis.

Acknowledgements This work has been carried out within the projects "Endocrine Control as a Determinant of Larval Quality in Fish Aquaculture" (CT-96-1422) and "Arrested development: The Molecular and Endocrine Basis of Flatfish Metamorphosis" (Q5RS-2002-01192), with financial support from the Commission of the European Communities. However, it does not necessarily reflect the Commission's views and in no way anticipates its future policy in this area. This project was further supported by the Swedish Council for Agricultural and Forestry Research and Pluriannual funding to CCMAR by the Portuguese Science and Technology Council.

\section{References}

Ayala AG, Villaplana M, Hernandez MPG, Pozo EC, Agulleiro B (2003) FSH-, LH-, and TSH-expressing cells during development of Sparus aurata L. (Teleostei). An immunocytochemical study. Gen Comp Endocrinol 134:72-79

Ball JN, Baker BI (1969) The pituitary gland: anatomy and histophysiology. In: Hoar WS, Randall DJ (eds) Fish physiology, II. Academic, New York, NY, pp 1-205

Batten TFC, Ingleton PM (1986) The hypothalamus and the pituitary gland. In: Chester-Jones I, Ingleton PM, Phillips JG (eds) Fundamentals of comparative vertebrate endocrinology. Plenum Press, New York, NY, pp 285-408

Björnsson BTh (1997) The biology of salmon growth hormone: from daylight to dominance. Fish Physiol Biochem 17:9-24

Björnsson BTh, Halldorsson O, Haux C, Norberg B, Brown CL (1998) Photoperiod control of sexual maturation of the Atlantic halibut (Hippoglossus hippoglossus): plasma thyroid hormone and calcium levels. Aquaculture 166:117-140

Björnsson BTh, Johansson V, Benedet S, Einarsdóttir IE, Hildahl J, Agustsson T, Jonsson E (2002) Growth hormone endocrinology of salmonids: regulatory mechanisms and mode of action. Fish Physiol Biochem 27:227-242

Bole-Feysot C, Goffin V, Edery M, Binart N, Kelly PA (1998) Prolactin (PRL) and its receptor: actions, signal transduction pathways and phenotypes observed in PRL receptor knockout mice. Endocr Rev 19:225-268

Brent GA (1994) The molecular basis of thyroid hormone action. N Engl J Med 331:847-853

Brown CL, Kim BG (1995) Combined application of cortisol and triiodothyronine in the culture of larval marine finfish. Aquaculture 135:79-86

Brown CL, Doroshov SI, Nunez JM, Hadley C, Vaneenennaam J, Nishioka RS, Bern HA (1988) Maternal triiodothyronine injections cause increases in swimbladder inflation and survival rates in larval striped bass, Morone saxatilis. J Exp Zool 248:168-176

Brown DD (1997) The role of thyroid hormone in zebrafish and axolotl development. Proc Natl Acad Sci USA 94:13011-13016

Buckbinder L, Brown DD (1993) Expression of the Xenopus laevis prolactin and thyrotropin genes during metamorphosis. Proc Natl Acad Sci USA 90:3820-3824 
Cambre M, Mareels G, Corneillie S, Moons L, Ollevier F, Vandesande F (1990) Chronological appearance of the different hypophysial hormones in the pituitary of sea bass larvae (Dicentrarchus labrax) during their early development: an immunocytochemical demonstration. Gen Comp Endocrinol 77:408-415

Chapman SC, Sawitzke AL, Campbell DS, Schoenwolf GC (2005) A three-dimensional atlas of pituitary gland development in the zebrafish. J Comp Neurol 487:428-440

Clemons GK, Nicoll CS (1977) Effects of antisera to bullfrog prolactin and growth hormone on metamorphosis of Rana catesbeiana tadpoles. Gen Comp Endocrinol 31:495-497

Cleveland R, Wolfe J (1932) A differential stain for the anterior lobe of the hypophysis. Anat Rec 51:409-413

Company R, Astola A, Pendon C, Valdivia MM, Perez-Sanchez J (2001) Somatotropic regulation of fish growth and adiposity: growth hormone $(\mathrm{GH})$ and somatolactin (SL) relationship. Comp Biochem Physiol C 130:435-445

Dales S, Hoar WS (1954) Effects of thyroxine and thiourea on the development of chum salmon (Oncorhynchus keta). Can J Zool 32:244-251

de Jesus EG, Hirano T, Inui Y (1994) The antimetamorphic effect of prolactin in the Japanese flounder. Gen Comp Endocrinol 93:44-50

de Jesus EGT, Toledo JD, Simpas MS (1998) Thyroid hormones promote early metamorphosis in grouper (Epinephelus coioides) larvae. Gen Comp Endocrinol 112:10-16

Deane EE, Woo NYS (2003) Ontogeny of thyroid hormones, cortisol, hsp70 and hsp90 during silver sea bream larval development. Life Sci 72:805-818

Derby A, Etkin W (1968) Thyroxine-induced tail resorption in vitro as affected by anterior pituitary hormones. J Exp Zool 169:1-6

Dodd MHI, Dodd JM (1976) The biology of metamorphosis. In: Lofts B (ed) Physiology of the amphibia, III. Academic, New York, NY, pp 467-599

Einarsdóttir IE, Sakata S, Björnsson BTh (2002) Atlantic halibut growth hormone: structure and plasma levels of sexually mature males and females during photoperiod-regulated annual cycles. Gen Comp Endocrinol 127:94-104

Forsyth IA, Wallis M (2002) Growth hormone and prolactin molecular and functional evolution. J Mammary Gland Biol Neoplasia 7:291-312

Fukamachi S, Sugimoto M, Mitani H, Shima A (2004) Somatolactin selectively regulates proliferation and morphogenesis of neural-crest derived pigment cells in medaka. Proc Natl Acad Sci USA 101:10661-10666

Glasgow E, Karavanov AA, Dawid IB (1997) Neuronal and neuroendocrine expression of $\lim 3$, a LIM class homeobox gene, is altered in mutant zebrafish with axial signaling defects. Dev Biol 192:405-419

Grandi G, Chicca M (2004) Early development of the pituitary gland in Acipenser naccarii (Chondrostei, Acipenseriformes): an immunocytochemical study. Anat Embryol 208:311-321

Grandi G, Colombo G, Chicca M (2003) Immunocytochemical studies on the pituitary gland of Anguilla anguilla L., in relation to early growth stages and diet-induced sex differentiation. Gen Comp Endocrinol 131:66-76

Greenblatt M, Brown CL, Lee M, Dauder S, Bern HA (1989) Changes in thyroid hormone levels in eggs and larvae and in iodide uptake by eggs of coho and chinook salmon, Oncorhynchus kisutch and Oncorhynchus tschawytscha. Fish Physiol Biochem 6:261-278

Gutt J (1985) The growth of juvenile flounders (Platichthys flesus) at salinities of $0,5,15$ and 35 percentages. Zeitsch Angew Ichthyol 1:17-26

Hadley ME (1992) Endocrinology. Prentice-Hall International, London

Herzog W, Zeng XC, Lele Z, Sonntag C, Ting JW, Chang CY, Hammerschmidt M (2003) Adenohypophysis formation in the zebrafish and its dependence on Sonic hedgehog. Dev Biol $254: 36-49$
Huang HC, Brown DD (2000a) Prolactin is not a juvenile hormone in Xenopus laevis metamorphosis. Proc Natl Acad Sci USA 97:195-199

Huang HC, Brown DD (2000b) Overexpression of Xenopus laevis growth hormone stimulates growth of tadpoles and frogs. Proc Natl Acad Sci USA 97:190-194

Huang L, Specker JL (1994) Growth hormone- and prolactinproducing cells in the pituitary gland of striped bass (Morone saxatilis): immunocytochemical characterization at different life stages. Gen Comp Endocrinol 94:225-236

Inui Y, Miwa S (1985) Thyroid hormone induces metamorphosis of flounder larvae. Gen Comp Endocrinol 60:450-454

Kakizawa S, Kaneko T, Hasegawa S, Hirano T (1993) Activation of somatolactin cells in the pituitary of the rainbow trout $\mathrm{On}$ corhynchus mykiss by low environmental calcium. Gen Comp Endocrinol 91:298-306

Kakizawa S, Ishimatsu A, Takeda T, Kaneko T, Hirano T (1997) Possible involvement of somatolactin in the regulation of plasma bicarbonate for the compensation of acidosis in rainbow trout. J Exp Biol 200:2675-2683

Kobuke L, Specker JL, Bern HA (1987) Thyroxine content of eggs and larvae of coho salmon, Oncorhynchus kisutch. J Exp Zool 242:89-94

Koibuchi N, Chin MW (2000) Thyroid hormone action and brain development. Trends Endocrinol Metab 11:123-128

Laiz-Carrion R, Segura-Noguera MD, del Rio MDM, Mancera JM (2003) Ontogeny of adenohypophyseal cells in the pituitary of the American shad (Alosa sapidissima). Gen Comp Endocrinol 132:454-464

Llewellyn L, Nowell MA, Ramsurn VP, Wigham T, Sweeney GE, Kristjánsson B, Halldórsson Ó (1999) Molecular cloning and developmental expression of the halibut thyroid hormone receptor-a. J Fish Biol 55:148-155

Mangelsdorf DJ, Thummel C, Beato M, Herrlich P, Schuetz G, Umesono K, Blumnberg B, Kastner P, Mark M, Chambon P, Evans RM (1995) The nuclear receptor superfamily: the second decade. Cell 83:835-839

McCormick SD (2001) Endocrine control of osmoregulation in teleost fish. Am Zool 41:781-794

Miwa S, Inui Y (1987a) Effects of various doses of thyroxine and triiodothyronine on the metamorphosis of flounder (Paralichthys olivaceus). Gen Comp Endocrinol 67:356-363

Miwa S, Inui Y (1987b) Histological changes in the pituitarythyroid axis during spontaneous and artificially-induced metamorphosis of larvae of the flounder Paralichthys olivaceus. Cell Tissue Res 249:117-123

Naito N, de Jesus EGT, Nakai Y, Hirano T (1993) Ontogeny of pituitary cell types and the hypothalamo-hypophysial relationship during early development of chum salmon, Oncorhynchus keta. Cell Tissue Res 272:429-437

Norris DO (ed) (1997) Vertebrate endocrinology. Academic, San Diego, CA

Okimoto DK, Weber GM, Grau EG (1993) The effects of thyroxine and propylthiouracil treatment on changes in body form associated with a possible developmental thyroxine surge during posthatching development of the tilapia, Oreochromis mossambicus. Zool Sci 10:803-811

Olsen Y, Evjemo JO, Olsen A (1999) Status of the cultivation technology for production of Atlantic halibut (Hippoglossus hippoglossus) juveniles in Norway/Europe. Aquaculture 176:313

Ono M, Takayama Y, Rand-Weaver M, Sakata S, Yasunaga T, Noso T, Kawauchi H (1990) Complementary DNA cloning of somatolactin, a pituitary protein related to growth hormone and prolactin. Proc Natl Acad Sci USA 87:4330-4334

Oppenheimer JH, Schwartz HL (1997) Molecular basis of thyroid hormone dependent brain development. Endocrinol Rev $18: 462-475$

Ozaki Y, Okumura H, Kazeto Y, Ikeuchi T, Ijiri S, Nagae M, Adachi S, Yamauchi K (2000) Developmental changes in pituitary-thyroid axis, and formation of gonads in leptocephali and glass eels of Anguilla spp. Fish Sci 66:1115-1122 
Pandolfi M, Paz DA, Maggese C, Ravaglia M, Vissio P (2001) Ontogeny of immunoreactive somatolactin, prolactin and growth hormone secretory cells in the developing pituitary gland of Cichlasoma dimerus (Teleostei, Perciformes). Anat Embryol 203:461-468

Perez-Sanchez J (2000) The involvement of growth hormone in growth regulation, energy homeostasis and immune function in the gilthead sea bream (Sparus aurata): a short review. Fish Physiol Biochem 22:135-144

Peter RE, Marchant TA (1995) The endocrinology of growth in carp and related species. Aquaculture 129:299-321

Power DM (1992) Immunocytochemical identification of growth hormone, prolactin, and gonadotropin cells in the pituitary of male plaice (Pleuronectes platessa) during gonadal maturation. Gen Comp Endocrinol 85:358-366

Power DM, Canario AVM (1992) Immunocytochemistry of somatotrophs, gonadotrophs, prolactin and adrenocorticotropin cells in larval sea bream (Sparus auratus) pituitaries. Cell Tissue Res 269:341-346

Power DM, Llewellyn L, Faustino M, Nowell MA, Björnsson BTh, Einarsdóttir IE, Canario AVM, Sweeney GE (2001) Thyroid hormones in growth and development of fish. Comp Biochem Physiol C 130:447-459

Reddy PK, Lam TJ (1992) Effect of thyroid hormones on morphogenesis and growth of larvae and fry of telescopic-eye black goldfish, Carassius auratus. Aquaculture 107:383-394

Renfro JL (1997) Hormonal regulation of renal inorganic phosphate transport in the winter flounder, Pleuronectes americanus. Fish Physiol Biochem 17:377-383

Rotllant J, Worthington GP, Fuentes J, Guerreiro PM, Teitsma CA, Ingleton PM, Balment RJ, Canario AVM, Power DM (2003) Determination of tissue and plasma concentrations of PTHrP in fish: development and validation of a radioimmunoassay using a teleost 1-34 N-terminal peptide. Gen Comp Endocrinol 133:146-153

Saele O, Solbakken JS, Watanabe K, Hamre K, Power D, Pittman K (2004) Staging of Atlantic halibut (Hippoglossus hippoglossus L.) from first feeding through metamorphosis, including cranial ossification independent of eye migration. Aquaculture 239:445-465

Saga T, Oota Y, Nozaki M, Swanson P (1993) Salmonid pituitary gonadotrophs. III. Chronological appearance of GTH I and other adenohypophysial hormones in the pituitary of the developing rainbow trout (Oncorhynchus mykiss irideus). Gen Comp Endocrinol 92:233-241

Saga T, Yamaki K, Doi Y, Yoshizuka M (1999) Chronological study of the appearance of adenohypophysial cells in the ayu (Plecoglossus altivelis). Anat Embryol 200:469-475

Santos CRA, Cavaco JEB, Ingleton PM, Power DM (2003) Developmental ontogeny of prolactin and prolactin receptor in the sea bream (Sparus aurata). Gen Comp Endocrinol 132:304-314

Sbrogna JL, Barresi MJF, Karlstrom RO (2003) Multiple roles for Hedgehog signaling in zebrafish pituitary development. Dev Biol 254:19-35

Schreiber AM, Specker JL (1998) Metamorphosis in the summer flounder (Paralichthys dentatus): stage-specific developmental response to altered thyroid status. Gen Comp Endocrinol 111:156-166

Shi YB, Wong J, PuzianowskaKuznicka M, Stolow MA (1996) Tadpole competence and tissue-specific temporal regulation of amphibian metamorphosis: roles of thyroid hormone and its receptors. Bioessays 18:391-399

Solbakken JS, Norberg B, Watanabe K, Pittman K (1999) Thyroxine as a mediator of metamorphosis of Atlantic halibut, Hippoglossus hippoglossus. Environ Biol Fish 56:53-65

Tagawa M, Hirano T (1987) Presence of thyroxine in eggs and changes in its content during early development of chum salmon, Oncorhynchus keta. Gen Comp Endocrinol 68:129-135

Tagawa M, Miwa S, Inui Y, DeJesus EG, Hirano T (1990a) Changes in thyroid hormone concentrations during early development and metamorphosis of the flounder, Paralichthys olivaceus. Zool Sci 7:93-96

Tagawa M, Tanaka M, Matsumoto S, Hirano T (1990b) Thyroid hormones in eggs of various fresh water, marine and diadromous teleosts and their changes during egg development. Fish Physiol Biochem 8:515-520

Takada M, Kasai M (2003) Growth hormone is a weaker candidate than prolactin for the hormone responsible for the development of a larval-type feature in cultured bullfrog skin. J Exp Biol 206:1137-1142

Tanaka M, Tanangonan JB, Tagawa M, deJesus EGT, Nishida H, Isaka M, Kimura R, Hirano T (1995) Development of the pituitary, thyroid and interrenal glands and applications of endocrinology to the improved rearing of marine fish larvae. Aquaculture 135:111-126

Tata JR, Kawahara A, Baker BS (1991) Prolactin inhibits both thyroid hormone-induced morphogenesis and cell-death in cultured amphibian larval tissues. Dev Biol 146:72-80

Tata JR, Baker BS, Machuca I, Rabelo EML, Yamauchi K (1993) Autoinduction of nuclear receptor genes and its significance. $\mathbf{J}$ Steroid Biochem Mol Biol 46:105-119

Villaplana M, Ayala AG, Hernandez MPG, Agulleiro B (1997) Ontogeny of immunoreactive somatolactin cells in the pituitary of gilthead sea bream (Sparus aurata L, Teleostei). Anat Embryol 196:227-234

Volckaert FAMa, Mugoyo JWM, Lescroart O, Grisez L, Ollevier F (1999) Immunohistochemically detected ontogeny of prolactin and growth hormone cells in the African catfish Clarias gariepinus. Comp Biochem Physiol 122:423-431

Wada T, Aritaki M, Tanaka M (2004) Effects of low-salinity on the growth and development of spotted halibut Verasper variegatus in the larva-juvenile transformation period with reference to pituitary prolactin and gill chloride cells responses. J Exp Mar Biol Ecol 308:113-126

Weltzien FA, Norberg B, Helvik JV, Andersen O, Swanson P, Andersson E (2003) Identification and localization of eight distinct hormone-producing cell types in the pituitary of male Atlantic halibut (Hippoglossus hippoglossus L.). Comp Biochem Physiol A 134:315-327

Wu YF, Koenig RJ (2000) Gene regulation by thyroid hormone. Trends Endocrinol Metab 11:207-211

Yadav BN (1995) The pituitary gland. In: Fish endocrinology. Daya Publishing House, Delhi, pp 24-60

Yamamoto K, Kikuyama S (1982) Effect of prolactin antiserum on growth and resorption of tadpole tail. Endocrinol Jpn 29:8185

Zhu Y, Thomas P (1997) Effects of somatolactin on melanosome aggregation in the melanophores of red drum (Sciaenops ocellatus) scales. Gen Comp Endocrinol 105:127-133 